\title{
PENGARUH DUKUNGAN SOSIAL KELUARGA TERHADAP PSYCHOLOGICAL ADJUSTMENT PADA KLIEN ASIMILASI (STUDI DI BALAI PEMASYARAKATAN KELAS II PATI)
}

\author{
Yuni Triana Hapsari \\ Direktorat Jenderal Pemasyarakatan \\ Kementerian Hukum dan Hak Asasi Manusia Republik Indonesia \\ yuni.triana.hapsari123@gmail.com
}

\begin{abstract}
In early 2020, the world including Indonesia was shocked by the presence of a new virus, namely SARS-CoV-2 or COVID-19. The government has taken various policies related to preventing the spread of COVID-19, one of which is in the Ministry of Law and Human Rights. Directorate General of Corrections (Ditjenpas) One way to accelerate the expenditure of prisoners and children is through the crash program of integration rights. Prisoners who are assimilated at home are then handed over to the Correctional Center (Bapas) for guidance and supervision when assimilating at home. After serving prison terms in prisons and detention centers and their families being repatriated due to the COVID-19 pandemic, they of course face various problems and psychological problems in their daily lives. To be able to survive with these conditions, humans must make psychological adjustments. In the process of adaptation to the environment, family social support is needed. This study aims to determine the relationship between family social support and psychological adjustment on assimilated clients at the Class II Correctional Center Pati. This study uses a quantitative approach. The research sampling process was carried out using simple random techniques, obtained 93 research samples. Data collection was carried out by distributing questionnaires and literature study. Data management was performed using the SPSS 25 program. Data collection used a family social support scale (43 items) and a psychological adjustment scale (36 items). Data analysis used simple regression analysis with the coefficient of determination $=0.676$ and the correlation coefficient $=0.822(p<5)$ with an effective contribution of $67.6 \%$. The results of this study indicated that there was a positive relationship between family social support and psychological adjustment for clients at the Class II Correctional Center in Pati.
\end{abstract}

Keywords: Client Assimilation, Family Social Support, Psychological Adjustment

\begin{abstract}
Abstrak: $\boldsymbol{A}$ wal tahun 2020, dunia termasuk Indonesia dikejutkan dengan adanya virus baru yaitu SARS-CoV-2 atau COVID-19. Pemerintah telah mengambil berbagai kebijakan terkait pencegahan penyebaran COVID-19, salah satunya yang ada di Kementerian Hukum dan Hak Asasi Manusia. Direktorat Jenderal Pemasyarakatan (Ditjenpas) Salah satu cara untuk mempercepat pengeluaran narapidana dan anak adalah melalui crash program hak integrasi. Narapidana yang mendapat asimilasi di rumah kemudian diserahkan ke Balai Pemasyarakatan (Bapas) untuk pembinaan dan pengawasan saat melakukan asimilasi di rumah. Setelah menjalani masa hukuman penjara di Lapas dan Rutan serta dipulangkan keluarganya akibat pandemi COVID-19, mereka tentunya menghadapi berbagai masalah dan problem psikologis dalam kehidupan seharihari. Untuk bisa bertahan dengan kondisi tersebut, manusia harus melakukan psychological adjustment. Dalam proses adaptasi dengan lingkungan dibutuhkandukungan sosial keluarga. Penelitian ini bertujuan untuk mengetahui hubungan dukungan sosial keluarga dengan psychological adjustment pada klien asimilasi di Balai Pemasyarakatan Kelas II Pati. Penelitian ini menggunakan pendekatan kuantitatif. Proses pengambilan sampel penelitian dilakukan dengan teknik acak sederhana, diperoleh 93 sampel penelitian. Pengumpulan data dilakukan dengan penyebaran kuesioner dan studi pustaka. Pengelolaan data dilakukan dengan menggunakan program SPSS 25. Pengumpulan data menggunakan skala dukungan sosial keluarga (43 item) dan skala psychological adjustment (36 item). Analisis data menggunakan analisis regresi sederhana dengan koefisien determinasi $=0,676$ dan koefisien korelasi $=0,822(\mathrm{p}<0,05)$ dengan sumbangan efektif $67,6 \%$. Hasil
\end{abstract}


penelitian ini menunjukkan ada hubungan yang positif antara dukungan sosial keluarga dengan psychological adjustment pada klien di Balai Pemasyarakatan Kelas II Pati.

Kata kunci: Klien Asimilasi, Dukungan Sosial Keluarga, Psychological Adjustment

\section{PENDAHULUAN}

Pada awal tahun 2020 dunia termasuk Indonesia digemparkan dengan virus baru yaitu SARS-CoV-2 atau yang lebih dikenal dengan Coronavirus disease 2019 atau COVID-19. Virus COVID-19 ini adalah virus zoonosis yaitu virus yang bermutasi pada hewan dan menular pada manusia. Tingkat risiko penularan COVID-19 sangat cepat karena dapat ditularkan antar manusia dengan sentuhan langsung dengan pembawa virus atau menyentuh benda yang sebelumnya telah disentuh oleh pembawa virus, virus ini ditularkan melalui droplets (Surico \& Galeotti, 2020). Data menunjukan bahwa penyebaran kasus COVID-19 terbanyak di 4 provinsi di Indonesia. Dengan total kasus positif sebanyak 9.096 dengan jumlah pasien meninggal sebanyak 765 dan pasien sembuh sebanyak 1.151 yang tersebar di seluruh provinsi Indonesia dan tingkat kenaikannya yang sangat cepat hal tersebut dapat di lihat pula dalam gambar perkembangan COVID-19 di seluruh Indonesia yang penyebarannya sangat signifikan setiap hari (Satgas Covid-19, 2020).

Pemerintah mengambil banyak kebijakan terkait pencegahan penyebaran COVID-19 salah satunya di Kementerian Hukum dan Hak Asasi Manusia. Direktorat Jendral Pemasyarakatan (Ditjenpas) dengan mengeluarkan beberapa kebijakan guna mencegah penyebaran virus corona yang sangat cepat terutama di dalam lingkungan Rumah Tahanan (Rutan), Lembaga Pemasyarakatan (Lapas) dan Lembaga Pemasyarakatan Khusus Anak (LPKA). Dengan salah satu cara dengan melakukan percepatan pengeluaran narapidana dan anak melalui suatu crash program hak integrasi yang telah berjalan sejak tahun lalu.

Melalui kebijakan pengeluaran narapidana dan anak yang ada di dalam lapas dan rutan seluruh Indonesia, diharapkan mampu mencegah dan menanggulangi penyebaran COVID-19. Terdapat 38.822 warga binaan pemasyarakatan yang telah mendapatkan program asimilasi maupun integrasi yang merupakan usaha untuk mencegah dan menanggulangi penyebaran Covid-19 di berbagai upt pemasyarakatan di seluruh Indonesis (Direktorat Jenderal Pemasyarakatan, 2019). Pemberian hak asimilasi itu pun dilakukan oleh pihak Lembaga Pemasyarakatan Kelas IIB Pati. Terdapat sebanyak 121 narapidana mendapatkan asimilasi terkait pandemi COVID-19 ini.

Warga binaan setelah menjalani masa pidananya di Lapas maupun Rutan dan telah dikembalikan keluarganya akibat pandemi COVID-19 ini tentunya menghadapi berbagai masalah psikologis maupun masalah dalam kehidupan sehariharinya seperti diabaikan oleh lingkungan 
terdekatnya terutama keluarga, berkurangnya dukungan sosial yang diterimanya, kehilangan kebebasan yang dimilikinya karena setelah keluar dari menjalani masa pidananya mereka juga tidak dapat bebas beraktifitas karena masih harus melaksanakan masa asimilasi dibawah pengawasan juga dengan adanya pandemi COVID-19 seluruh masyarakat serba dalam pembatasan, kehilangan hak untuk menentukan sesuatu sendiri, serta kehilangan rasa aman(Meilina, 2013). Manusia sejatinya dikenal sebagai makhluk sosial, tidak jauh dari interaksi dengan makhluk lain baik dengan keluarganya maupun dengan lingkungan sekitarnya. Tidak dipungkiri, individu yang baru keluar dari Lapas akan mengalami situasi yang penuh dengan stres.

Setelah individu keluar dari Lapas dapat menjadikan seseorang dalam kondisi stres. Beberapa masalah lainnya yang sering muncul pada warga binaan pemasyarakatan menurut Kartono dan Sholicatun dalam tulisan Raisa (2016) seperti timbulnya konflik dalam diri seseorang, pengalaman traumatis, gangguan kepribadian, perilaku seksual menyimpang, menutup diri, emosi yang sulit dikontrol, cemas, curiga berlebihan, sulit menyesuaikan diri, jenuh, merindukan lingkungan sosialnya, tidak siap menerima kenyataan, hilangnya rasa percaya diri, menjadi pelaku kejahatan yang lebih parah dari sebelumnya, dan bahkan sampai melakukan tindakan bunuh diri (Raisa \& Ediati, 2016).

Oleh sebab itu, dukungan sosial sangat diperlukan oleh para warga binaan untuk mengontrol kondisi mental mereka agar menimbulkan perilaku positif dan dapat mengurangi perilaku negatif dari warga binaan itu sendiri. Dukungan keluarga juga dapat mengurangi tingkat stres mereka. Wargabinaan yang mengalami kondisi stres atau depresi diakibatkan oleh gagalnya mereka untuk beradaptasi terhadap situasi lingkungan baru yang mereka harus jalankan. Seperti halnya yang disampaikan oleh Hidayat (1998) menyatakan bahwa pada manusia, perubahan kondisi lingkungan sangat mudah menimbulkan tekanan atau stres pada manusia (Hidayat, 1998).

Untuk dapat bertahan dengan kondisi tersebut, manusia harus melakukan psychological adjustment atau dengan kata lain penyesuaian diri oleh karena itu maka seorang warga binaan harus dapat beradaptasi dengan baik di lingkungannya. Dalam proses beradaptasi dengan lingkungan sangat diperlukan dukungan sosial. Apabila lingkungan sekitar dari warga binaan memberikan dukungan sosial kepada dirinya yang baru saja bebas dari hukuman pidana maka yang akan dirasakan individu tersebut adalah timbulnya rasa nyaman dan dapat bertahan di lingkungan tersebut, namun sebaliknya apabila individu merasa tidak menerima dukungan dari sesama warga binaan maupun keluarganya, maka mereka akan merasa tertekan secara psikologis dengan lingkungannya (Aulia, 2018).

Dukungan emosional yang diberikan oleh lingkungan akan menimbulkan rasa yang baik 
dan lega dalam menghadapi masalah karena dia mendapatkan bantuan dalam menyelesaikan permasalahan yang sedang dihadapi. Secara tidak langsung perlakuan tersebut membuat anggota keluarga yang mempunyai masalah tersebut merasa diperhatikan dan membuat dirinya termotivasi untuk bangkit dari permasalahan yang sedang hadapi. Seperti halnya yang dialami oleh warga binaan, mereka tidak akan mengalami tekanan akibat baru dipulangkan dari menjalani pidana di Lapas, jika mendapatkan dukungan dari orang sekitar maupun orang-orang yang dicintainya sehingga dirinya tidak akan merasakan kesepian dalam menjalankan hari-harinya. Namun sebaliknya apabila warga binaan tersebut selama berada di rumah tidak mendapatkan dukungan sosial dari orang-orang sekitar maupun orang-orang yang dicintainya, tidak mempunyai tempat untuk berkeluh-kesah atas permasalahan dan beban yang sedang ia jalani, hal ini akan memberikan pengaruh negatif bagi psikologis dan kesehatan narapidana tersebut, baik akan mempertinggi tingkat stres maupun hal yang buruk lainnya.

Dukungan sosial yang diberikan kepada warga binaan untuk dapat melakukan psychological adjustment ketika ia masih menjalankan asimilasi di rumah. Menurut peraturan pemerintah no 31 tahun 1999 tentang Pembinaan dan Pembimbingan Warga Binaan Pemasyarakatan menjelaskan bahwa asimilasi adalah proses pembinaan narapidana dan anak didik pemasyarakatan yang dilaksanakan dengan membaurkan narapidana dan anak didik pemasyarakatan dalam kehidupan masyarakat. Proses asimilasi dapat dilakukan di dalam Lapas (intramural) maupun di luar Lapas (ekstramural). Namun dengan adanya pandemi COVID19 ini Kementerian Hukum dan HAM RI khususnya Direktorat Pemasyarakatan memutuskan untuk memberikan para warga binaan asimilasi di rumah.

Berdasarkan uraian latar belakang diatas, permasalahan yang akan dibahas dalam penelitian ini adalah Bagaimana pengaruh dari dukungan sosial keluarga terhadap psychological adjustment pada klien asimilasi di Bapas Kelas II Pati selama menjalankan tahap asimilasi guna penyesuaian setelah keluar dari Lapas?

\section{METODE}

Dalam penelitian ini peneliti menggunaan metode pendekatan kuantitatif. Penelitian ini bertujuan untuk mencari hubungan antara dua atau lebih yang memiliki suatu hubungan sebab akibat terhadap variabel lainnya (Sugiyono, 2015). Metode kuantitatif yang digunakan oleh penulis adalah metode survei.

Penelitian ini menggunakan jenis korelasional antara variable bebas yaitu dukungan sosial dengan variable terikat yaitu Psychological Adjustment pada narapidana yang mendapatkan asimilasi di Bapas Kelas II Pati. Kedua variabel tersebut biasanya diukur dengan menggunakan suatu instrumen penelitian sehingga data yang terdiri dari kumpulan 
angka dapat dianalisis berdasarkan prosedurprosedur statistik. Populasi dalam penelitian ini ialah keseluruhan warga binaan pemasyarakatan yang mendapatkan pembebasan bersyarat asimilasi saat pandemi COVID-19 di Balai Pemasyarakatan Kelas II B Pati. Berdasarkan data yang diperoleh dari hasil jumlah narapidana yang mendapatkan asimilasi saat pandemi COVID-19 di Balai Pemasyarakatan Kelas II B Pati berjumlah 121 warga binaan. Sampel yang digunakan ialah 93 responden dengan menggunakan rumus Slovin.

Instrumen yang digunakan yaitu instrumen sebagai alat ukur dukungan sosial dan instrumen sebagai alat ukur skala Psychological Adjustment. Skala untuk mengukur dukungan sosial diadaptasi oleh skala milik peneliti terdahulu Sarah Afifah (2019) yang disusun berdasarkan teori Weiss dalam Tumanggor, Ridho, \& Nurochim (2017) menjelaskan bahwa ada enam aspek yang membentuk dukungan sosial. Adapun aspek dari dukungan sosial tersebut adalah kelekatan emosional (emotional attachment), integrasi sosial (social integration), adanya pengakuan (reassurance of worth), ketergantungan yang dapat diandalkan (reliable reliance), bimbingan (guidance) dan kesempatan untuk mengasuh (opportunity for nurturance). Skala tersebut tersusun dalam bentuk skala likert yang berisi 48 item yang telah disesuaikan dengan keadaan warga binaan.
Sedangkan skala untuk mengukur tingkat Psychological Adjustment warga binaan diambil dari skala milik peneliti terdahulu Alifatul Firda (2018) yang disusun menggunakan teori psychological adjustment oleh DeVito (1981) menyatakan bahwa terdapat 6 aspek dari psychological adjustment yakni realita persepsi (Perception of Reality), kecemasan (Anxiety), harga diri (Selfesteem),depresi (Depression), penguasaan lingkungan (Environmental mastery) dan kemarahan (Anger). Skala tersebut tersusun dalam bentuk skala likert yang berisi 36 item yang telah dimodifikasi sesuai dengan keadaan klien pemasyarakatan.

\section{HASIL}

Hasil perolehan data primer dari penyebaran kuesioner yang diberikan pada 93 orang responden yang merupakan klien di Bapas Kelas II Pati, maka diperoleh data berdasarkan jenis kelamin responden tersebut dapat dilihat bahwa klien di Bapas Kelas II Pati berjenis kelamin laki-laki, yaitu sebanyak 91 orang atau sebesar 97,8\% sedangkan klien yang berjenis kelain perempuan sebanyak 2 atau sebesar $2,2 \%$.

Berdasarkan usia responden tersebut dapat dilihat bahwa klien di Bapas Kelas II Pati adalah klien berusia <20 tahun, yaitu sebanyak 8 orang atau sebesar $8,6 \%$ dari total 93 responden, 28 orang atau sebesar $30,1 \%$ berusia 21-30 tahun, 16 orang atau sebesar $17,2 \%$ berusia $31-40$ tahun, 1orang atau sebesar $1,1 \%$ berusia 39 - 
40 tahun, kemudian yang berusia 41-50 tahun, yaitu sebanyak 18 orang atau sebesar $19,4 \%$ dari total 93 responden, 18 orang atau sebesar 19,4\% berusia 51-60 tahun, 4 orang atau sebesar 4,3\% berusia 61-70 tahun.

Berdasarkan pendidikan terakhir yang diperoleh responden tersebut menunjukan bahwa dari 93 orang responden yaitu 31 orang atau 33,3\% memiliki pendidikan terakhir SD, 35 orang atau $37,6 \%$ memiliki pendidikan terakhir SMP, kemudian sebanyak 24 orang atau $33,7 \%$ dari SMA, dan sebanyak 3 orang atau $3,2 \%$ berasal dari Sarjana. status perkawinan menunjukkan bahwa mayoritas klien di Bapas Kelas II Pati adalah 63 orang atau $67,7 \%$ berstatus menikah sisanya adalah terdapat 30 orang atau $32,3 \%$ masih belum menikah.

Sebanyak 28 orang atau sebesar $30,1 \%$ responden bekerja sebagai buruh, 2 orang atau $2,2 \%$ seorang pelajar, 14 orang atau $15,1 \%$ tidak memiliki pekerjaan atau pengangguran, 7 orang atau $7,6 \%$ bekerja sebagai sopir, 11 orang atau $11,8 \%$ bekerja di swasta, 21 orang atau $22,6 \%$ bekerja sebagai wiraswasta, 10 orang atau $10,8 \%$ memiliki pekerjaan lainnya.

\section{Hasil Uji Validitas}

Peneliti melalukan uji validitas menggunakan 30 responden awal yang diperoleh dari klien pemasyarakatan yang mendapatkan asimilasi di luar lokus penelitian kemudian diolah dengan menggunakan software IBM SPSS 25 guna menguji valid atau tidaknya suatu pernyataan. Berdasarkan hasil uji validitas yang telah dilakukan, terlihat bahwa nilai $r$ Pearson Correlation setiap butir pernyataan dalam variabel dukungan sosial (variabel bebas) menunjukan nilai hitung yang lebih besar dari nilai $r$ table. Ada 48 butir pernyataan dalam variabel bebas yang valid dan

36 butir pernyataan dalam variabel terikat yang valid.

\section{Uji Reliabilitas}

Terdapat 48 pernyataan variabel bebas kemudian didapatkan hasil reliabilitas sebagai berikut :

\section{Tabel 1. Uji Reliabilitas Dukungan Sosial} Keluarga

\begin{tabular}{cr}
\hline \multicolumn{2}{c}{ Reliability Statistics } \\
\hline $\begin{array}{c}\text { Cronbach' } \\
\text { s Alpha }\end{array}$ \\
\hline, 976 & 48 \\
\hline
\end{tabular}

Nilai Cronbach's Alpha sebesar 0,976 dari 48 item pernyataan. Angka tersebut mengidikasikan bahwa alat ukur memiliki reliabilitas yang tinggi untuk menjadi alat ukur penelitian. Selain itu, terdapat 36 pernyataan variabel terikat dan didapatkan hasil reliabilitas sebagai berikut :

Tabel 2. Uji Reliabilitas Psychological Adjustment

\begin{tabular}{|c|c|}
\hline \multicolumn{2}{|c|}{ Reliability Statistics } \\
\hline $\begin{array}{r}\text { Cronbach' } \\
\text { s Alpha }\end{array}$ & $\mathrm{N}$ of Items \\
\hline 953, & 36 \\
\hline
\end{tabular}

Nilai Cronbach's Alpha sebesar 0,953 dari 36 item pernyataan. Angka tersebut mengidikasikan bahwa alat ukur memiliki 
reliabilitas yang tinggi untuk menjadi alat ukur penelitian.

\section{Uji Korelasi}

Uji korelasi ini digunakan untuk melihat seberapa besar variabel bebas mempengaruhi variabel terikatnya.

Tabel 3. Uji Korelasi

\begin{tabular}{|c|c|c|c|}
\hline \multicolumn{4}{|c|}{ Correlations } \\
\hline & & $\begin{array}{l}\text { Dukungan } \\
\text { Sosial }\end{array}$ & $\begin{array}{l}\text { Psychological } \\
\text { Adjustment }\end{array}$ \\
\hline Dukungan Sosial & $\begin{array}{l}\text { Pearson } \\
\text { Correlation } \\
\text { Sig. (2-tailed) }\end{array}$ & 1 & $\begin{array}{l}, 822 * \\
, 000\end{array}$ \\
\hline \multirow{3}{*}{$\begin{array}{l}\text { Psychological } \\
\text { Adjustment }\end{array}$} & $\mathrm{N}$ & 93 & 93 \\
\hline & $\begin{array}{l}\text { Pearson } \\
\text { Correlation } \\
\text { Sig. (2-tailed) }\end{array}$ & $\begin{array}{l}, 822^{*+} \\
, 000\end{array}$ & 1 \\
\hline & $\mathrm{N}$ & 93 & 93 \\
\hline
\end{tabular}

Berdasarkan tabel hasil uji korelasi tersebut terlihat bahwa nilai pearson correlation antara variabel dukungan sosial keluarga dengan variabel psychological adjustment yaitu 0,822. Hasil tersebut menerangkan bahwa hubungan di antara keduanya bersifat kekuatan korelasinya ke arah positif. Artinya, jika variabel dukungan keluarga dari klien tinggi maka psychological adjustment klien tinggi. Sebaliknya, jika variabel dukungan keluarga dari klien rendah maka psychological adjustment klien rendah.

\section{Uji Regresi}

Dalam penelitian ini, digunakan model regresi linier sederhana yang hasilnya dapat dilihat dari beberapa tabel berikut :

Tabel 4. Uji Regresi

\begin{tabular}{llccr}
\hline \multicolumn{4}{c}{ Model Summary } \\
\hline Model & $\mathrm{R}$ & R Square & $\begin{array}{c}\text { Adjusted R } \\
\text { Square }\end{array}$ & $\begin{array}{r}\text { Std. Error of } \\
\text { the Estimate }\end{array}$ \\
& & & & \\
1 &, $822^{\mathrm{a}}$ &, 676 &, 673 & 2,055 \\
Predictors: (Constant), Dukungan Sosial & &
\end{tabular}

Berdasarkan tabel diatas menunjukkan bahwa model yang digunakan dalam penelitian adalah satu variabel bebas dan variabel terikat dengan nilai koefisien determinasi ( $\mathrm{R}$ Square) sebesar 0,676, dan nilai korelasi (R) sebesar 0,822. Dimana nilai korelasi (R) memiliki arti bahwa variabel dukungan sosial memiliki hubungan yang sangat kuat dalam memprediksi variabel psychological adjustment. Besar angka koefisien determinasi ( $\mathrm{R}$ Square) sebesar 0,676 atau 67,6 memiliki arti bahwa variabel dukungan sosial memiliki pengaruh terhadap variabel psychological adjustment sebesar $67,6 \%$ sedangkan sisanya $32,4 \%$ dipengaruhi oleh variabel lain yang tidak diteliti.

\section{PEMBAHASAN}

Dukungan sosial dapat bersumber dari keluarga, teman, tetangga, atau bahkan penyedia jasa kesehatan. Dalam penelitian ini, yang dijadikan sumber dukungan sosial adalah keluarga karena narapidana membutuhkan dukungan sosial jangka panjang. McLeroy, Gottlieb, dan Heaney dalam Nurhidayati, N., Nurdibyanandaru (2014) mengatakan bahwa dukungan sosial jangka panjang biasanya bersumber dari keluarga. Lee dalam Lestari, (2016) juga menyebutkan bahwa keluarga inti (nuclear family) memiliki pengaruh yang besar bagi individu. Dalam penelitian ini, yang dimaksud dengan keluarga inti adalah ayah, ibu, dan saudara kandung bagi individu 
yang belum menikah atau istri dan anak bagi individu yang menikah.

Peran dari keluarga inti dalam mendampingi untuk melalui masa- masa sulit sangat membantu secara positif dan signifikan. Keluarga di Indonesia juga terbiasa hidup dalam hubungan kekerabatan yang kuat dan erat, kesulitan dan masalah dapat membuat hubungan keluarga semakin kuat (Pratiwi, I. Kartasasmita., Rachmawati, S., \& Puspitasari, 2017) Nayana dalam (Azhima \& Indrawati, 2018) mengatakan bahwa kondisi sosio-emosional individu dipengaruhi oleh keluarga yang saling menyayangi dan menerima antar individu sehingga berdampak positif pada kepuasan diri masing-masing individu. Hal ini yang kemudian memengaruhi psychological adjustment setelah mereka keluar dari lapas.

Dampak positif dukungan sosial keluarga juga dapat dilihat dalam penelitian ini. Dalam penelitian ini, hubungan antara dukungan social keluarga dengan psychological adjustment pada klien pemasyarakatan memiliki nilai koefisien korelasi sebesar 0,676.

Dalam penelitian ini, peneliti menemukan bahwa dukungan sosial keluarga memberi sumbangan efektif sebesar $67,6 \%$ terhadap psychological adjustment, sedangkan $32,4 \%$ dipengaruhi oleh faktor lainnya yang tidak diteliti dalam penelitian ini..

\section{SIMPULAN}

Hasil dari penelitian tersebut mendukung penelitian yang dilakukan oleh peneliti, menunjukan hasil dukungan sosial keluarga dan psychological adjustment (penyesuaian diri). Dapat disimpulkan hal ini menunjukan bahwa terdapat kesamaan antara penelitian terdahulu dan penelitian yang peneliti lakukan, hasil dari penelitian yang dilakukan penliti adalah berdasarkan hasil yang diperoleh setelah melakukan uji hipotesis dengan teknik analisis regresi sederhana menunjukkan nilai koefisien korelasi sebesar 0,676 dengan nilai signifikansi $\mathrm{p}=0,000$ dimana $0,000<0,05$. Nilai yang diperoleh dari koefisien korelasi dan signifikansi di atas menunjukkan bahwa ada hubungan positif antara dukungan sosial keluarga dengan psychological adjustment pada klien pemasyarakatan di Bapas Kelas II Pati. Nilai positif juga menunjukkan bahwa arah hubungan antar kedua variabel positif, dimana semakin tinggi dukungan sosial keluarga maka semakin tinggi psychological adjustment, dan juga sebaliknya. Oleh karena itu, hipotesis yang diajukan peneliti dalam penelitian ini bahwa ada hubungan positif antara dukungan sosial keluarga dengan psychological adjustment dapat diterima.

\section{DAFTAR RUJUKAN}

Aulia, A. F. (2018). Psychological Adjustment Dan Resiliensi Pada Narapidana Lembaga Pemasyarakatan Perempuan Klas Iia Malang Skripsi. 
Malang: Fakultas Psikologi. Universitas Muhammadiyah Malang.

Azhima, D. D., \& Indrawati, E. S. (2018). Hubungan Antara Dukungan Sosial Keluarga Dengan Subjective WellBeing Pada Narapidana Perempuan Di Lembaga Pemasyarakatan "“ X ." 7(April), 308-314.

DeVito, A. J. (1981). The Measurement of Psychological Adjustment in Hispanics. Retrieved from http://proxy.lib.umich.edu/login?url=http:// search.ebscohost.com/login.aspx?direct $=\mathrm{tr}$ ue \& db=eric\&AN=ED217366\&site=ehostlive \&scope $=$ site

Hidayat, T. (1998). Stres Dalam Lingkup Pekerjaan. Psikologi Jiwa, 229-441. Husnayain, I. (2007). Analisis Ekonomi Kejahatan Properti di Indonesia. Jurnal Ekonomi., 20 (9), 59-60.

Keputusan Menteri Hukum Dan HAM RI No.M.HH-19 PK.01.04.04 Tahun 2020 Tentang Pengeluaran Dan Pembebasan Narapidana Dan Anak Melalui Asimilasi Dan Integrasi Dalam Rangka Pencegahan Dan Penanggulangan Penyebaran Covid-19

Lestari, T. (2016). Asuhan keperawatan anak. Nuha Medika.

Liputan6.com. (2020). Sudah 38.822 Napi dan Anak Dikeluarkan dari Lapas Cegah Pandemi Covid-19. Retrieved April 20, 2020, from Liputan6.com website:

https://www.liputan6.com/news/read/4232 098/sudah-38822-napi-dan-anak-i dikeluarkan-dari-lapas-cegah-pandemicovid-19

Meilina, C. (2013). Dampak Psikologis Bagi Narapidana Wanita Yang Melakukan Tindak Pidana Pembunuhan Dan Upaya Penanggulangannya. Jurnal Ilmiah, Fakultas Hukum, Universitas Brawijaya. Malang.
Nurhidayati, N., Nurdibyanandaru, D. (2014). Hubungan antara Dukungan Sosial Yang, Keluarga dengan Self Esteem pada Penyalahguna Narkoba Mental, Direhabilitasi. Jurnal Psikologi Klinis Dan Kesehatan, 03(03).

Pemerintah Republik Indonesia. Undangundang Nomor 12 Tahun 1995 tentang Pemasyarakatan (1995). Republik Indonesia.

Peraturan Pemerintah No 31 Tahun 1999 Tentang Pembinaan Dan Pembimbingan Warga Binaan Pemasyarakatan Menjelaskan Bahwa Asimilasi Adalah Proses Pembinaan Narapidana Dan Anak Didik Pemasyarakatan Yang Dilaksanakan Dengan Membaurkan Narapidana Dan Anak Didik Pemasyarakatan Dalam Kehidupan Masyarakat.

Peraturan Menteri Hukum Dan HAM RI Nomor 10 Tahun 2020 Tentang Syarat Pemberian Asimilasi Dan Hak Integrasi Bagi Narapidana Dan Anak Dalam Rangka Pencegahan Dan Penanggulangan Penyebaran Covid-19

Pratiwi, I. Kartasasmita., Rachmawati, S., \& Puspitasari, D. N. (2017). Psychology for daily life. Jakarta : Rajawali Pers.

Sarah Afifah Nasution, N. F. (2019). Hubungan Antara Dukungan Sosial Keluarga Dengan Kebahagiaan Pada Narapidana Di Lembaga Pemasyarakatan Kelas I Semarang. Jurnal Empati, 9, Nomer 1, 15-21.

Sugiyono. (2015). Metode Penelitian Kuntitatif, Kulitatif dan R\&B. Bandung: Alfabeta.

Surico, P., \& Galeotti, A. (2020). The economics of a pandemic: the case of Covid-19. London Business School Lecture, (March), 3, 4.

Tumanggor Rusmin, Ridho Kholis, N. (2017). Ilmu Sosial dan Budaya Dasar (ketiga). Jakarta: Kencana. 